UDC 622.83

\title{
岩石破壊音による崩落予知に関する研究*
}

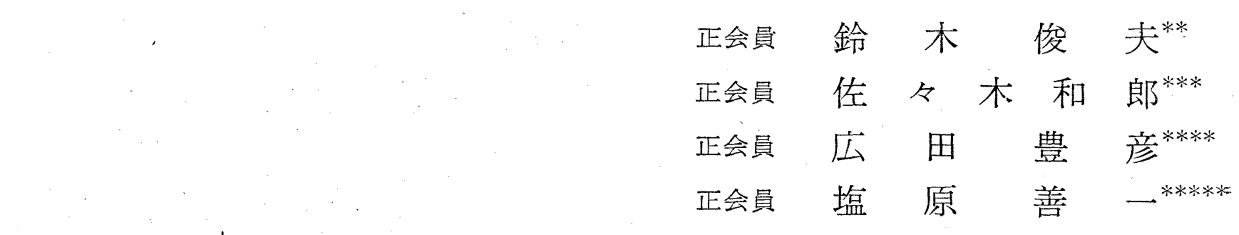

\section{Studies on the Prediction of Rock Failure by Counting Subaudible Noise of Rock}

Toshio SUZUKI, Kazuro SASAKI, Toyohiko HIROTA and Zen-ichi SHIOHARA

\begin{abstract}
Generally, any displacement or disturbance in the rock creates an impulse or rock noise and the count of this rock noise increase according to the increase of the stress of rock. Consequently, if the rock noise were measured continuously, the rock failure would be predicted. This is the basic principle of this method of predicting rock failure. This principle was found about 20 years ago, but this prediction method have not been applied in the field, yet.

In the beginning, we studied at the laboratory with several kinds of rock specimen on the following: items :

1. wave form of the rock noise

2. frequency spectrum of rock noise

3. relation betweeen rock noise rate and stress, then, we measured rock noise in the underground of some metal mines and the rate of occurrence of rock noise in the field were analysed.

Through these studies at laboratory and field, it was supposed that the rock failure would be predicted by counting the rock noise and an rock noise counter was developed.
\end{abstract}

\section{1. 緒}

\section{言}

一般に固体に荷重が加わる場合，その荷重が固体の破 斌倚重近くになれば，ある種の音が発生することはよく 知られていることである。岩石，石炭等の場合にもこれ と同様な現象がみられ，この音は岩石の破壊間近になれ ば直接耳で聞くことも出来るが，ある種の装置を用いれ ば，この音は破壞に至るかなり前から発生していること ボわかる。

この音の発生は, 岩石強度と荷重とに関連があり，ま た岩石の種類にようて異なるが，この音の発生状況を観 測することによつて, 岩八ネ, 岩盤の崩落等を予知しよ らといら試みは，すでに1940年代に実施されたが122), 当 時は箺用の段階には至らなかつた。最近になつて，また この方面の研究も進められているが，筆者等も岩石の破 壞音を利用して崩落等を予知する方法は，計測法に改良

\footnotetext{
* 昭和 37 年 5 月 23 日受理

日本釷業会昭和 33 年度秋季大会および36年度春季大会にて発表

** 工博 資源技術試験所 第 6 部長

**** 工博 資源技衔試験所 第 6 部第 1 課長

*****資源技術試験所 第 6 部第 1 課 (現北海道支所)

******資源技術試驗所第 6 部第 1 課
}

を加えるならば実用に供し得るものと考えて，岩石の破 壞音の特性並びにその計測法について実験室において基 礎的研究を進めるとともに，鉱山の現場において実測を 、行ない検討を行なつてきたが，実用の見透しが得られた ので，その結果について報告する。

\section{2. テストピースについての岩石破壊音}

岩石に詨する荷重が漸次増加し，ついにはこれが破壊 に至る間，どのような音が，どのような状態で発生する かを知ることは, 最も基本的な問題であるので, 各種の 岩石試料に対して圧縮荷重を加え, その時に発生する破 壞音の特性について測定を行なつた。

\section{$2 \cdot 1$ 測定装置並びに方法}

測定装置のブロックダイヤグラムを第 1 図に示す。す なわら, 整形した円壔状あるいは角壔状の岩石試料に対 して, 一定速度にて荷重を漸増し, その際に発生する破 壊音 (微小振動) をピックアップにより電気的出力に変 換し, これを増幅後, オクターブフィルタにより各周波 数に分け, エンベローパを通して電磁オシロあるいはペ ン書きオシロに記録する一方, 必要に応しては, この音 をテープレコーダに録音し，また，ブラウン管オシロに 


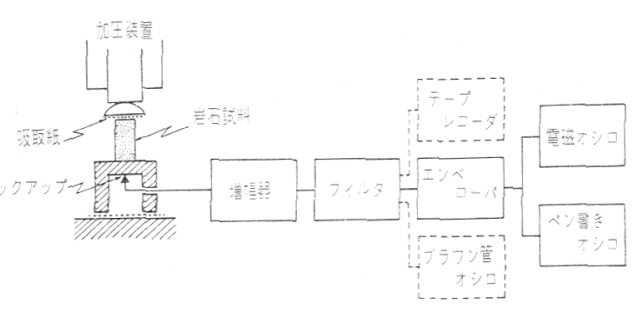

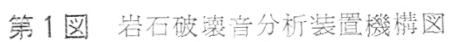

より観測した。なお，ピックアップとしては、ロッシエ 儿塩製その他妾使用したが，これは試料設置台（鋼製） の重面に敢付け，試料中を伝わる破壊音を対象として計 測するようにした。フィルタレインジとしては種々組合 わせることが出来るが，A(2〜 4kc/s)，B(4〜8kc/s)，… ‥F ( 64 128kc/s) の上うな範囲老使用した。上述のエ ンベローパは高い周波数の振動店応答速度の遅いオシロ グラフに記録させるため，振動波形そのものではなく， 交たかも振動波形のエンベロープ(包絡線) 者画かせる ような機能存有するもので，本研究のために特に考案し たものである。第2図は原波形とエンベローパの出力波 形も対比したものであり，このエンベローパの働きによ

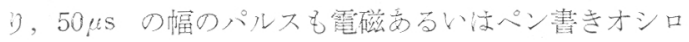
代記録することが出来る。

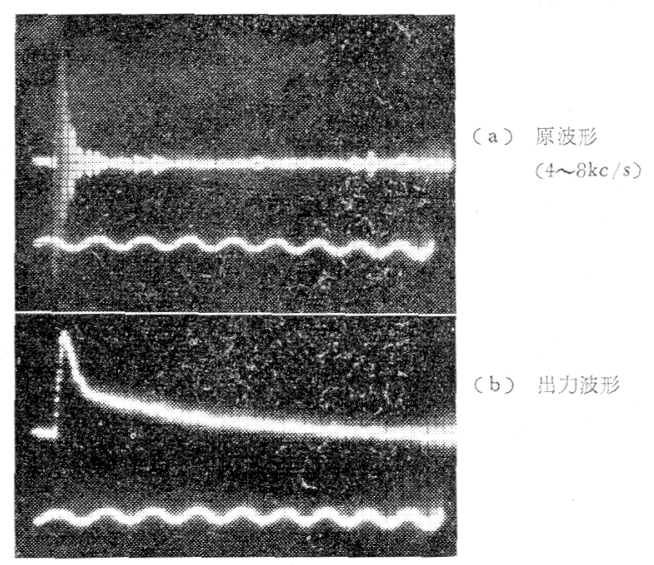

第 2 図ニンベローパ出力波形 (侍間目盛 $50 \mathrm{c} / \mathrm{s}$ )

\section{$2 \cdot 2$ 測定結疁}

種及の岩石試料に対して压縮荷重を加え，破壊音の振 動波形について観測するとともに，荷重と破壊音の周波 数との関係について測定を行なつた。

$2 \cdot 2 \cdot 1$ 破壊音の振動波形 第3 図は, 岩石破壊音の波 形 (岩石試料：粘板岩) の一例老示したものであるが， この波形からもわかるように，岩石破壞音は定常的な連 続音ではなく，衝撃音であつて極めて短時間に減衰する パルス様の振動であり, 音響学的には雑音に近い要素を 含み，この波形のみから法，乙の周波数成分走正確に知

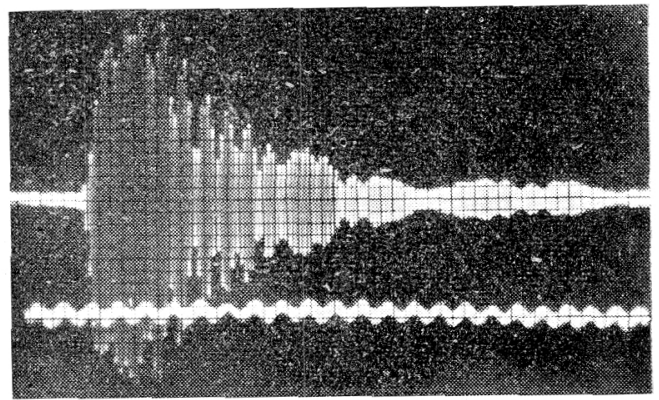

試料：粘板岩，时间回盛：1,000 c/s

筹了圈岩石破懐音の波形の一例

ることは不可能である。そこで, 岩石破壊音をテープレ コーダに録音し，こ机をオタターブフィルタにより分析 した。第4四は破猿音の分析結果の一例去示したものだ あるが，この例では $600 \mathrm{c} / \mathrm{s}$ 以下， $4,800 \mathrm{c} / \mathrm{s}$ 以上の周波数 成分は小さく, $600 \sim 4,800 \mathrm{c} / \mathrm{s}$, 殊飞 600 2, 400 c/s の 周波数成分兮大きい。しかし，他の例では，乙の周波数 成分はさらに広範国にわたつており, 数 $100 \mathrm{c} / \mathrm{s}$ から数 $100 \mathrm{kc} / \mathrm{s}$ に皮ぶものるあり，一般に破壊音は広い周波数 スペクトル交している。

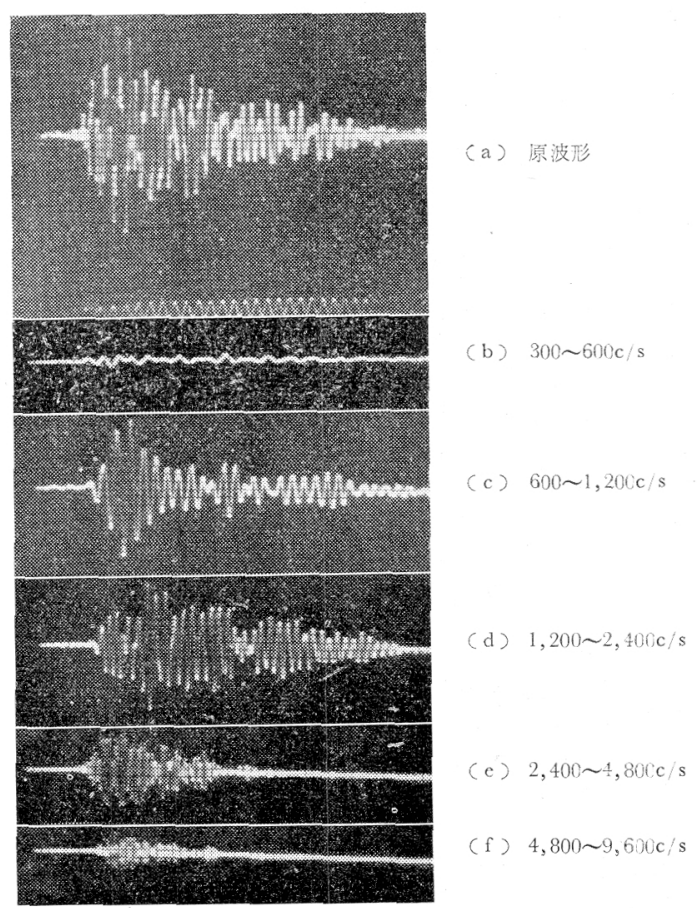

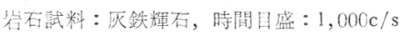

第4图䂟石破壞音の周波数分析波形の一例

$2 \cdot 2 \cdot 2$ 荷重と破坮音の閔係 岩石に荷重を加えた場 合の荷重と破壞音の発生数との関係については, こ狆ま でも発表されているが，テストピース(乾燥状態)に一 


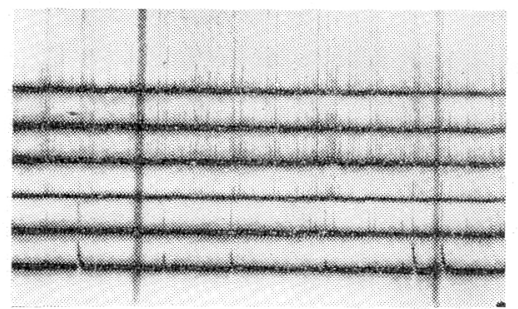

周波粒 $(\mathrm{kc} / \mathrm{s})$

第 5 図 破填音の記録例（電磁オシロ）

定速度にて荷重を加え，その間に発生する音をオクター ブフィルタにより各啵数成分に分け，電磁オシロに記 録した一例老第 5 図に示した。これ等の記録結果(ペン
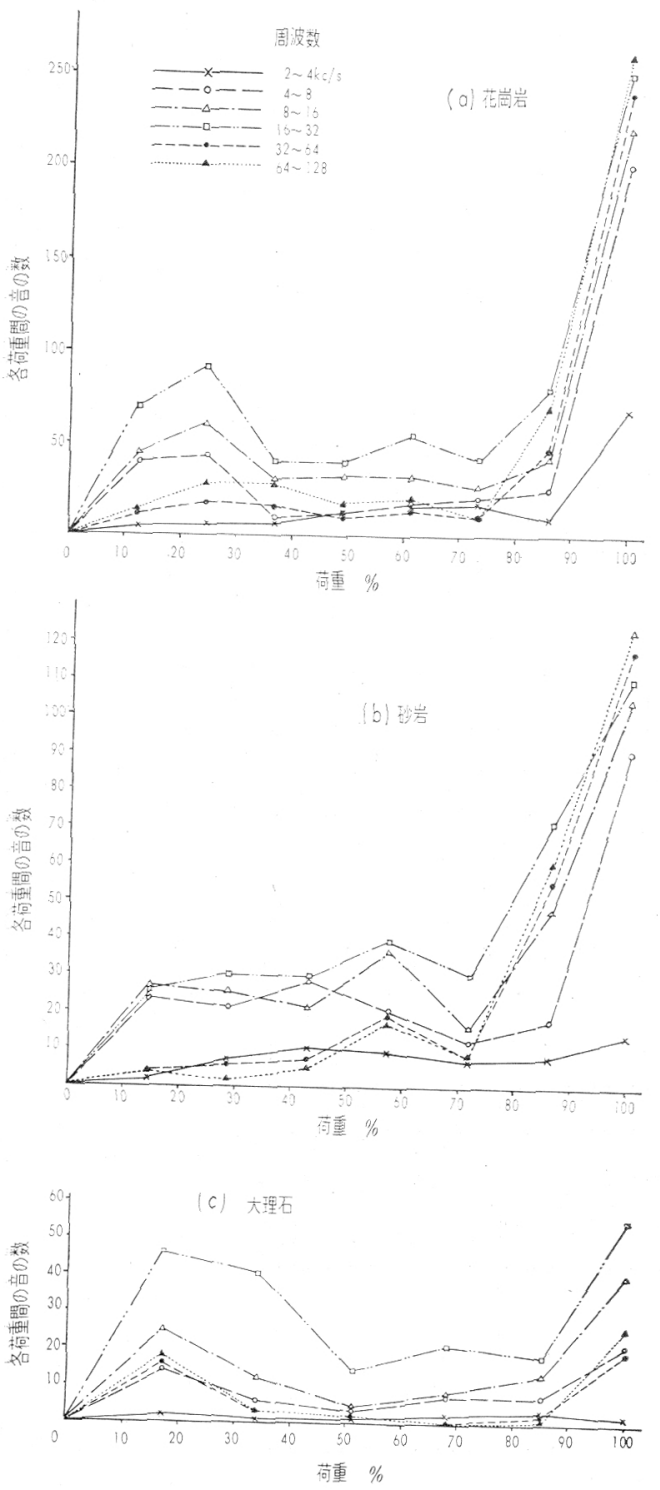

第6 図荷重と破壞音の哭係(乾燥試料)
書きオシ口在使用した場合も㐫るから，求めた荷重し 破壊音の発生数との関係の数例を第 6 図に示した。な 㧍，この場合，荷重はそのテストピースの破壞荷重に対 するパーセンテージをるつてあらわし, 破壞音は谷周波 数成分別に計数した。

これ等の結果をみるに，破墑音娢岩石上も概し一高 い周波数成分を含んでいる。また, 破壊音の何れの周波 数部分を対象にして考えても, 概して, 炣重の增大に庆 して音の数流大する傾向を示しているが，中でも，こ の傾向は，周波数の高い成分を対象二する場合に顕著に あらわれることが多い。なお，岩石の敇類によつては，

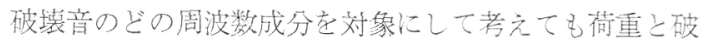
壊音の発生数との関係が明確でないものがあるが(例え ばある種の砂岩)，この種の岩石は，破壤音により崩落 老予知するに法不適当な岩種ということが出来るのでは

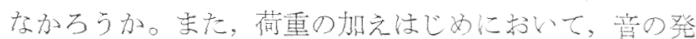
生数が非常に多いものも見受けられるが、これはテス卜 ピースの端面の不平行，凹凸等にも原因があるものと考 えられる。

第6四は乾燥したテストピースについての測定結果て あるが，テストピースが湿潤なる場合には，その破壊音 の周波数成分は，乾燥した場合とは異なるものと考えら れる。第7四は，二三の湿㵎試料につい下求めた破壊音 の周波数分析の結果であるが，これ主乾燥試料の之れと 対比してみるならば，試料が湿㵎なる場合には，乾燥し ている場合に比心゙，概して高い周波数成分老含む破壞 音が少なく，水分があたかも潤滑㶡の役目をはたしてい
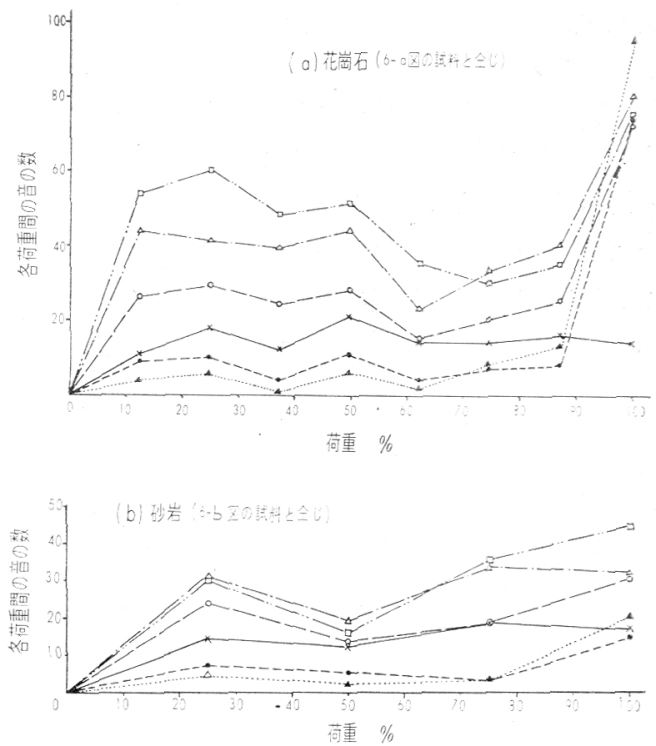

(周波数の区分等 6 戍之同し)

第 7 図荷重と破墥音の関媇（湿潤試料） 
るよらに見受けられる。この傾向は吸水性の大きな岩種 について特汇顥著にあらわれる傾向がある。

\section{3. 現場における岩石破壊音の計測}

実験室に扮いて岩石試料に加圧した場合, 荷重の增加 に応して破壞音の增加が認为られた。しかし, テストピ 一スについての実験に竌いては, その加圧速度が現場に 扔ける地圧変化速度之注全く異なり, 荷重方向も異なり またテストピースと実際の岩盤とではその大きさが極端 に異なる等，実験室と現場とで注条件が大きく相違する ため, 実験室の計測結果より直ちに現場に㧍ける岩石の 破䘫音の発生状況を推測することは出来ない。しかし， 実験室に打ける実験結果から推測すると, ある地圧下に 存在する岩盤中には, テストピースについて得られたと 同稼な岩石の破壊音の存在が認文られるはずであるので 実際に現場において破壊音の計測を行なつた。

\section{$3 \cdot 1$ 計測装置および計測方法}

現場測定索行ならに当つては, 岩石の破壊音自体法実 験室で得られるもの上同様と考えられるが，之の発生頻 度は不明であること，他の機械的あるいは電気的雑音の 混入のおをれがあること、ピックアップの位置と計測位 置とは時には相当距離がある等，実験室における測定と は計測条件も異なるので, 計測法もその条件に適したも のを選ばなけ秃ばならない。本測定を実施するに当つて

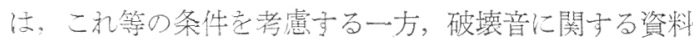
を, 上り多く求め, 解析を容易にするた河, ピックア

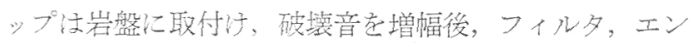
ベローパを通してペン書きオシロに記録する方法在採用 した。この測定樣式はピックアップの部分老除いては， 実験室汇打行万測定様式（第1図参照）上同様であり， 装置も実験室のものをそのまま利用したが、へッドアン プのみ法特に坑内使用汇便なるように, トランジスタ式 の小型，軽量のもの越いた。

すなわち，現場測定においては，ピックアップは坑内 における取扱いに際しての破損を防止し, 岩盤への固 定, 雜音防止等の必要上, ホルダ中に㧤さ的, 岩盤のボ アホール中に固定することを原則とした。ホルダ中にピ ックアップを执さあこのプローブの形は, 外径 $40 \mathrm{~mm}$ 程度の先端が円錐状の円简形であり，とくにボアホール の深部（孔口より数10 m 深部) にプローブを設置する場 合には，孔口からその固定操作を行ならことの出来る特 別仙設計したプローブを使用した。なお，ピックアップ としてはチタン酸バリウム、ロッシエル塩などの圧電型 と電磁型の両方を用いた。

プローブにより電氛量化変換された破壞音は，へッド アンて゚により增幅され (約 $80 \mathrm{db}$ ), フィルタにより坑内 作業等化基らく雑音老除く一方, 最も气の岩石の破壊音
の特徴となる周波数成分を選び出す。なお，この場合， 対象岩石の破壊音の周波数汇関する特徴活。㐫らか心゙ テストピースについて実験室に抢いて測定しておきっこ の結果を参考にして選ぶベき周波数成分を定める。次 に，この沪波された破壞音はエンベローパによりその振 動波形が変えられ, ペン書きオシロ汇記録, 計測され る。この際, 必要に応しては爾後における破壞音の解析 に利用するために，破壊音はテープレコーダに録音し た。

なお，プローブをボアホール内に固定した後は，ボア ホールのロを粘土等で密閉してプローブが空気中の音を 拾わないよら注意した。また, 通常, テ゚ローブの位置と 計測装置の位置とは数10m離れており，この間を接ぐケ ーブルが電気的雑音を拾うお肪れがあるので, へッドア ンプのみは出来るだけプルーブに近く配置して電気的雑 音が計測值に混入しないよう留意した。

第8図は，坑内における計測装置を示したものであ る。

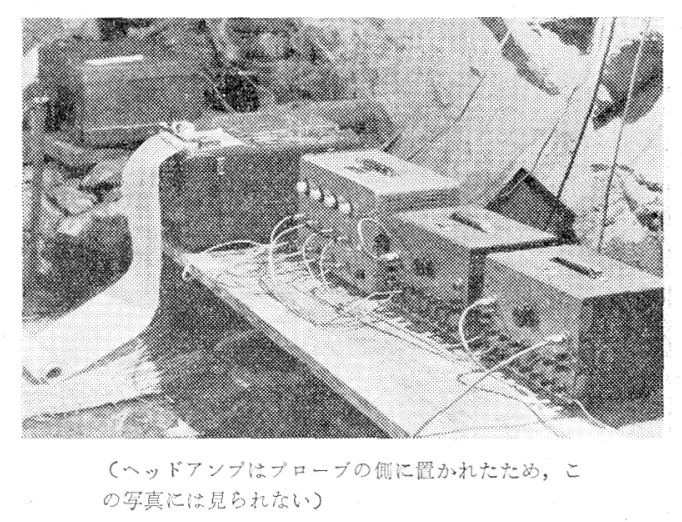

第 8 图坑内に置かれ心計測装置

\section{$3 \cdot 2$ 測定結果}

現場測定は，二三の金属鉱山において行なつた。

$3 \cdot 2 \cdot 1$ 発破後における岩石破壊音の变化：第 9 図ば A鉱山の坑内に扔いて坑道側壁に対して発破をかけた場 合 (岩質: 珪質角閃岩, 装薬量: $100 \mathrm{~g} \times 1$ 本) rの発破後 における音の発生数の時間的変化を示したものであるが 薬量が少ないため, 破壤音注 $10 \mathrm{~min}$ 足らずで安定状態 に大つている。第10図は, B 鉱山の玾内, 採掘跡周辺部 に扮いて, 装薬量 $100 \mathrm{~g} \times 300$ 本により, 約 $30 \mathrm{~m}^{3}$ 老起研 した時の岩石破壞音の発生と時間との関倸を示したもの で亦る。なお，この岩石比対する破壊音の周波数分析を テストピー大について行なつた結果を参考のために示す ならば第11図のようである。この現場測定に执いては, 破壊音は連続して10時間ペン書きオシ口に記録し(周波 数成分としては 2,400 9, 600 c/s 兵選しだ)，これにつ いて計数を行なつたが，発生頻度注便宜上１１０min 当り 


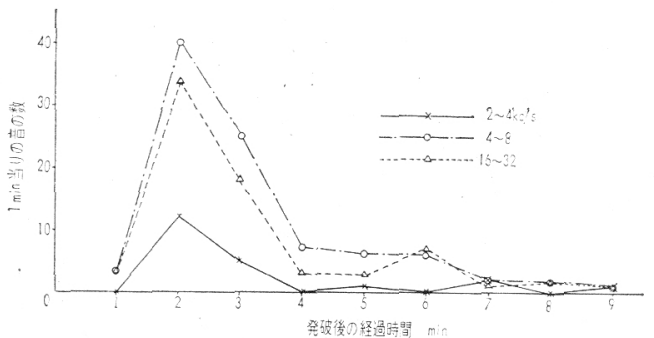

第9圈発破後に扣愔の発生数の時間 的变作 ( $\mathrm{A}$ 銀山)

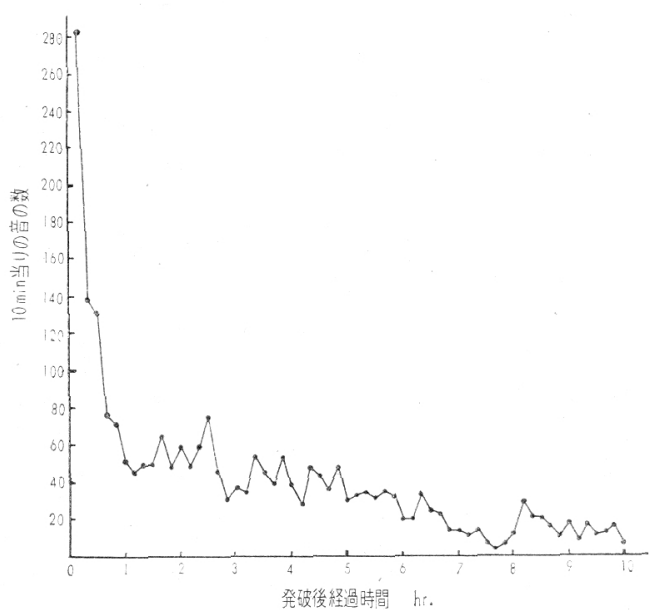

第10圈発破後に沶ける音 $(2,400 \sim 9,600 \mathrm{c} / \mathrm{s})$ の発生数の時間的变化 $(\mathrm{B}$ 鉱山

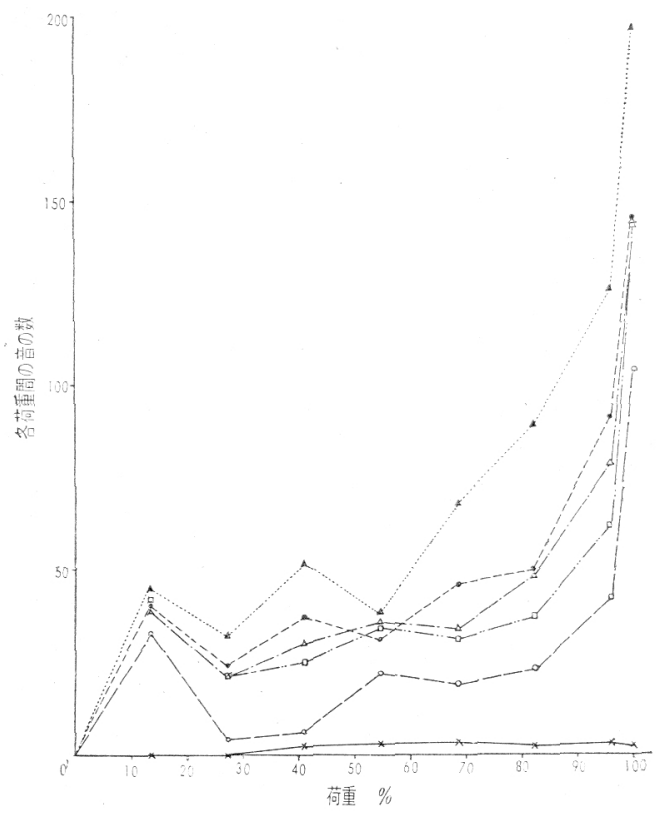

(周波数の区分法第 6 㘠々司じ)

第11図B鉣山の吡石に対与る荷重と破壊 音の関係
のカウント数であらわした。第12図は，その記録例の一一 部を示したものである。この結果をみるに，発破の影響 の大きいのは発破後 1 時間程度までであり, 以後は漸減 して8時間以上経過すれば，発破の影響消え消えりこ の測定場所にお打る地圧に起因した恒常的岩石破塙音 —いわゆるバックゲラウンドノイズ——とでも称す心゙ き音が引続いて発生している。

第13図はC鉱上において行なつた同様な測定結果（岩 質: 粘板岩, 装薬量：100g × 105 本, 起砕量：約 $8 \mathrm{~m}^{3}$ ) 定示したものであるが，この場合は破壊音の発生数が少 なかつた関係上，発生頻度をあらわすのには1 hr 当りの

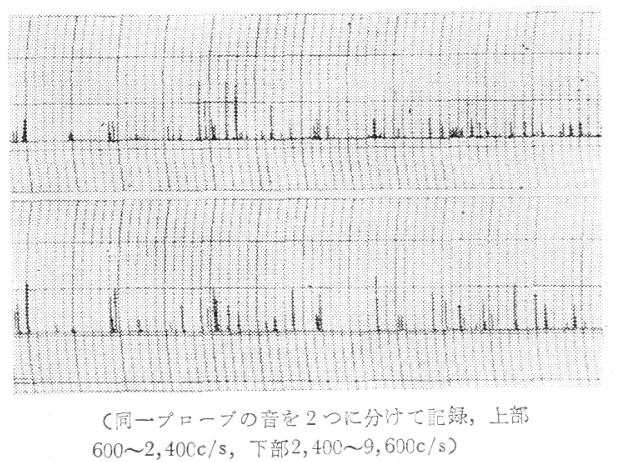

第12図 岩石破瓖音の現場記録の一部

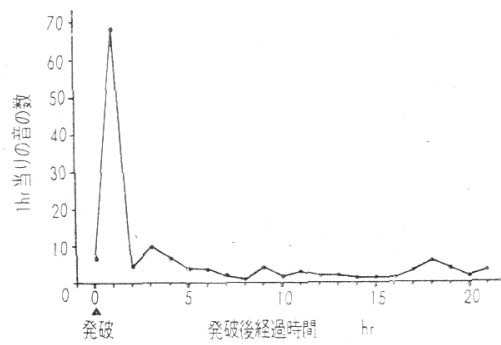

簐13図 登破後におけ名音(2000 8000 c/s $)$ の発生数の時間的変化 ( C 鉱山)

カウン下数在もつてした。この場合は，2 時間目に泣昨 にバックグラウンドノイズのレミルに落着いている。

以上の測定結果をみるに，発破の規模，岩質等によつ て破䘫音の絶対数（破䇠音の絶対数は, 計測装置の感度 によつても大幅に異なる）は異なるとはいえ，何れの場

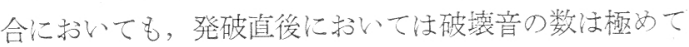
多いが，これは急激に減少し，爾後は㰾減手る傾向去 している。これは平衡状態にあつた岩盤内応力の平衡が 発破により破れ，発破㨁後に打いては不安定な状態老現 出するが，この不平衡の大部分活急激に回復し，以後岩 盤は安定状態に大るためと推測される。この過程は, 地 压吕漸增し遂に注崩落に至万過程の好たか子逆の過程に 


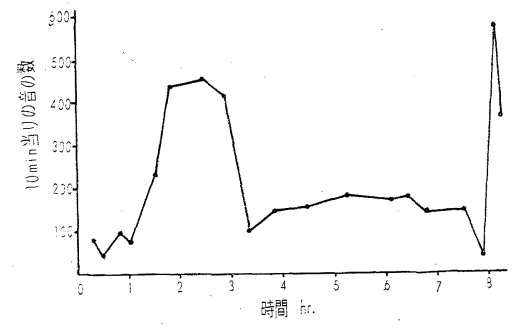

$(f=2,400 \sim 9,630 \mathrm{c} / \mathrm{s})$

第14図宣常的な岩石破壞音の発生状況

類似しており，発破後における時間と破壊音の関係を知 ることにより, 破壊音が漸増して崩落に至る過程を推測 し得るものと考えられている2’3)。

$3 \cdot 2 \cdot 2$ 測定位置にこる岩石破壞の梁化：同一鈗山の 同一岩種についても, 地表からの深度, 周囲の採掘状態 等により，破懐音の恒常的発生状況は異なる。

第14図はB 鉱山の鉱柱内において測定した岩石破壊音 の発生頻度を示したものである。この鉱柱は，その内部 に地圧の増大に伴なう亀裂の発生をみるなど，ほとんど 破壊に達しており，地圧も徐々にではあるが増加してい る状態にあつた（地圧は，光弾性ガラスおよび地圧計に より，その変化を，破壊音の計測後測定した結果，6力 月閒に $4 \sim 6 \mathrm{~kg} / \mathrm{cm}^{2}$ 増大していることが判明した)。こ の测定結果を第10図に示した測定結果と比較してみるに 両測定において, その岩質は同様であり, また, 測定感 度, 周波数成分は共に同様に選んだにもかかわらず，鉱 柱内に打注破填音発生数は極めて多く, $10 \mathrm{~min}$ 当り 200４00カウント程度，時にはそれ以上の值を示してお り, このカウント数注第10図に示した発破直後の最も不 安定な状態のカウント数に匹敵している。

また，別途C鉱山の各レベルにおいて破壊音を計測し 結果

$\begin{array}{cl}\text { 地表か } 5 \text { の深度 } & \text { カウント数 } \\ -25 \mathrm{~m} & \sim 0.04 \text { カウン } \mathrm{h} / \mathrm{hr} \\ -30 & \sim 0.3 \\ -45 & \sim 3 \\ -90 & \sim 10\end{array}$

安となるのではなかろうか？この問題については，今 、後とも，地圧测定と並行して検討を進めてゆく予定であ る。

\section{4. 考察}

実験室においては，テストピースに街重を加え，岩石 破壊音の振動波形，荷重と破壊音との関係について研究 する一方，現場においては，発破後における時間と破懷 音との関係，恒常的岩石破壊音の発生状況等について観 測を行なつた。その結果, 岩盤中にも, その岩石のテス トピースについて得られたと同様な周波数スペクトルを 有する破壊音の存在が確認され，また，この破壊音の数 池地あるいは岩盤の安定度に関連を有し, 破壊音の発 生頻度の変化を知るならば, 崩落の予知も可能になるも のとの見透しも得られたが，実際に現場において破壊音 の計測を行ならに当つては, 考慮す心゙き問題も多いので, 計測法その他主なる問題点について検討を行なつた。

\section{$4 \cdot 1$ 各計測方式の比較}

現段階において考えられる破壊音の計測方式を図示示 れば第15図のようであり，各方式にはそれぞれ長短があ る。

破壞音のピックアップ法について考えてみるに, 空気 を介してマイク等を通して計測する場合 ${ }^{4)}$ と, ピックア ップ(プローブ) を直接岩盤に取付けるか，あるいは岩 盤に固着させたスチールロッド等に取付け（水を介して 音をピックアップする場合も考えられる),これを増幅し て計測する場合とがある。前者の空気索介する場合にお いては，破壞音の振動が岩盤中を通り空気中に伝播され るとき, 岩盤と空気との界面にお打る反射が強く, 空気 中に伝播される振動エネルギーは極めて小さく，したが つて，この振動を対象として計測を行なう場合には堌幅 度を大幅に高めなければならず，また，この場合空気中 の雑音の竝害も受け易い。これに反して，岩盤に直接ピ ックアップを取付ける場合は，岩盤中を伝わる破填音の 振動を直接感受するため，岩盤と空気の界面における振 動エネルギーの減衰がなく, 感度の点において極めて有

程度のカウント数を得た。この結果 をみるに，深度が大なるほど，単位 時間当りのカウント数は大になる傾 向を示している。

単位時間当りの破壊音の発生数を もつて，ただちに地圧の大小を推測 することは危険ではあるが，上記の 実測例から考えて, 岩質が同一であ る場合, 感度, 周波数成分を同一に したカウント数(恒常的破壊音の数) つ多少は，地圧の大小を推測する目

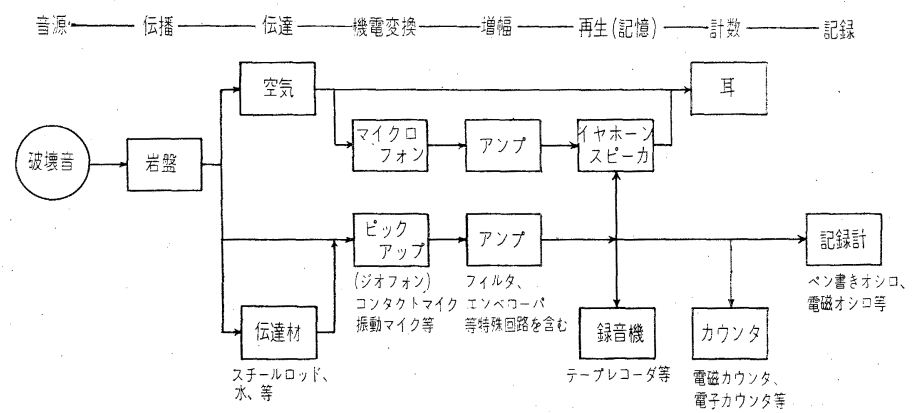

第15図 各種計測方式のブロックダイヤグラム 
利である。

計数法としては, 破壞音刀数ばかりではなく, 出来得 机化壊音のエネルギー, 周波数, 発生間隔等をも計測 し得ることが望ましい。計数方式としては，(1) 耳で開 いて数える方式，(2) 電磁式, 電子管式あるいはモータ 式計数装置等を用いる方式 ${ }^{5)}$ ，(3) 電磁オシ口，ペン書 きオシロ等による記録計数方式，等が考えられるが，こ れ等の中，上記の計測条件を满足するものとしては（3） の方式が考光られる。(1) の方式は簡単であり,また, 雑音と破壞音の区別もある程度まではなし得るという長 所流るが，個人差がある，長時閒測定が困難である等 問題も多、。

\section{$4 \cdot 2$ 計測上の主なる問題点}

岩石の破壊音を計測することにより崩落を予知する方 法を実際に滴用するに当つては，いろいろ問題点もある が，主なるもの二三について述べる。

1. 雑音：岩石の破壊音を計測するに当つては, 何れ の計測方式，装置を用いるにしても，岩石破壊音を他の 雑音と混同することなく正確に計数しなければならな w。

（1）空間雑音 岩石破壊音の観測には極めて高度の 増幅を行なう関係上，ピックアップが空氮中の音を拾う こともあるので，プローブは空間に露出することなく， 例えばブローブをボアホール中に固定し，ボアホールの 口元を粘土等で塞いで音から㢈蔽することが必要であ る。

(2) 電気的雑音 坑内には多くの電気機器があり, また，多くの電線も敷設されている。また，一方岩盤中 には，これ等の漏洩あるいは誘導に基ずく迷走電流も存 在している。このような坑内において，ピックアップの 位置から離れて計測を行なら場合には，一般にその間を 接ぐケーブルが, 電線や迷走電流の誘導を受けて電気的 雑音を拾い，岩石破壞音と混合して堌幅器に送り込まれ 計測される。この雑音は, 今回の現場測定においては, 極めて破壊音に類似しており，耳で聞きわけることも， フィルタにより除去することも出来なかつた。しかし， これはピックアップにヘッドアンプを出来るだけ接近さ せること, 究極に扔いては増幅器の一部をピックアップ とともにプルーブ中に収め, ケーブルを通る破壊音のレ ベルを雑音のレベルよりも極度に高めることにより解決 された。このようなことを考えるならば，たとえ電気的 雑音の存在が確認されない場合でも, 計測を正確に行な うためには, プルーブにはピックアップとともに増幅器 を内蔵させることが望ましい。

（3）機械的雑音 坑内作業に伴う振動は岩盤中を伝 播してピックアップに到達し, 岩石破壊音の計測を妨害 するが，この雑音の除去にはフィルタの利用が有効であ
る。

一般的機械的雑音は, その発生源においては極めて広 い周波数スペクトルを有しているが，こ礼が岩盤中を伝 播する間の減衰は，周波数によつて異なるので，ある距 離離れた点においては，その周波数スペクトルも異なつ てくる。すなおち，機械的雑音が岩盤中を伝播する間に おいて，岩盤自体があたかもフィル夕の㗢きをなし，周 波数の高いものほど大きく減衰するので6)，機械的雑音 源からある距離離れた点には, 比較的周波数の低、波し か到達しないことになる。したがつて，一般的には雑音 源上り西る距離離れれば（この距離は雑音源の周波数ス ペクトル，振幅，岩盤の減衰率等によつて異なる）比較 的高、周波数成分を多く含む岩石破壊音とは周波数の点 において大きな差異が生ずるので，弁別は容易になり， 低周波部をフィルタでカットすれば雑音の混入を防ぐこ とが出来る。しかし，音のエネルギーが強大に過ぎる場 合は，たとえフィルタを使用しても，完全にこれを除く ことは不可能であるので，この場合は，坑内作業を休止 している時間あるいは日を選んで計測を行ならことが望 ましい。

2. 計測感度 : 岩石破壊音の発生状態が同一であつて も, 計測感度が異なれば計数し得る破壊音の数は異なり 感度が低ければ音の数は少なく数えられる。したがつて とくに崩落予知のために破壊音を計測する場合には，長 期間にわたる破壊音の発生頻度の変化を知らねばならな いので, 計測装置の感度は, ピックアップをも含めて常 に一定に保た斌な゙ならないなお，ピックアップとして は圧電型と電磁型を使用したが, 経年変化, 耐湿性, 温 度特性等の点において，実用には電磁型のものが適する と考えられる。

3. 計測時間：破壊音の計測を行ならに当つては，1 回の計測時間㧍よび計測間隔を, 破壊音の発生頻度の変 化が正確に把握されるよう選ばるばならない。すなわち 第13図および第14図の例にみられるように，恒常的破壊 音の発生頻度は必ずしも一定したものではなく，したが つて，1回の計測時間を比較的短かく選ぶならば，その 計数值は数倍あるいはそれ以上異なることも起り得るの で，計測時間を定めるに当つては，この点充分注意しな ければならない。今回の実測例のような連続計測は望ま しいことではあるが，業務として計測を実施する場合に は必ずしもその必要はなく，休憩時間，夜間あるいは休 日等日時を定めて一定時間計測を行ない，その結果を記 録しておけげ充分であると考えられる。

\section{5. 結言}

岩石破壊音を利用する崩落予知法の実用化を目して， 岩石破壊音の特性, 計測装置および計測法について実験 


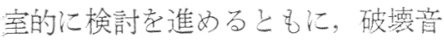
につけて二三の鈗山で現場計測を行 度った。

その結果，プローブ，アンプ，フ イル夕，エンベローパおよびペン書 きオシロの組合せにより，正確汇岩 石破壞音を計測することが出来，坑 内污打る岩石破壊音の登生状況す 偘かな例ではあるが明らかとなっ た。この結果，岩石破壞音の專用計 測装置も製作され(16図)，崩落予知 対策として岩石破瀤音の連続計測を 開始した鉱山も要る7)。しかし，本 予知法により, どの程度崩落を予知

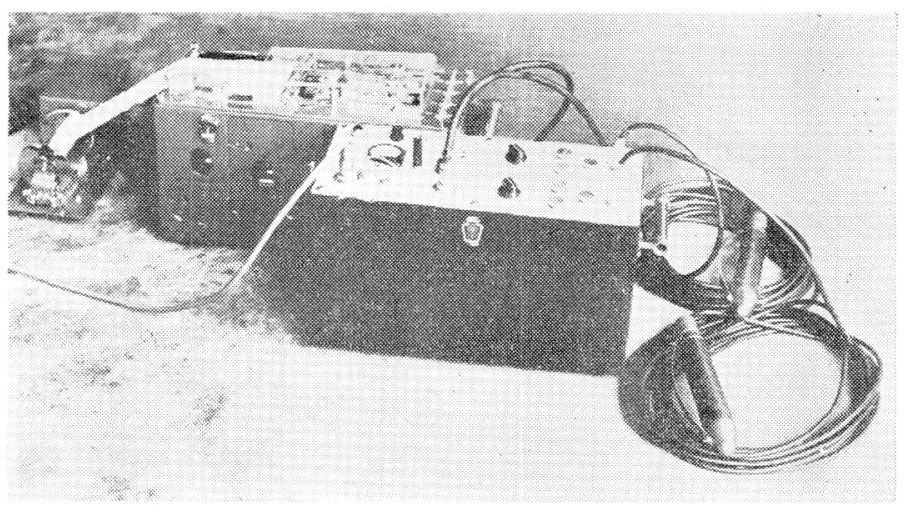

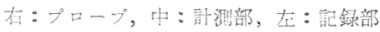

第16図 亳用計測装置
乙得るか⿰ついては, 未だ寒測例をなく, 確認されてい ないので, 今後は，地圧計测等と併せて広く現場計測觉 行ない，その予知の信頼性について検討定進めると共に 計測装置についても改良を行ない，上り簡易化するよう 研究を進めて师き度いと思う。また，このような破壊音 の計測法はソ連等で研究されているようにガス突出の予 知等にも利用の途が考えられるので，この方面への応用 についても検討を進める予定である。

本研究実施する化当つて注, 前黒川工業技術院長の 理解ある御援助を頂くとともに, 現場測定を行なうに当 つては，各鉱業所長をはじ担当各位の理解ある御協力 を賜わつた。また，実験に際しては，当試験所第 6 部近 門，戸辺再技官の協力老得た。ここ汇深甚なる謝意老表
する次第である。

\section{参考文献}

1) Leonard Obert: Use of Subaudible Noises for the Prediction of Rock Bursts, Part I, U. S. Bureau of Mines, R. I. 3555, Jan. 1941.

2) Leonard Obert and Wilbur Duvall: 局上, Part II, U. S. Bureau of Mines, R. I. 3654, July 1942.

3) Lloyd E. Antonides: How You Can Predict Rock Falls, E. M. I. Dec. 1955.

4) 日中。麻生：落盤予知飞関与古基憷的研究， 年稻田大学理工学部鉱山学所究報告 第 6 巻 第 68,69 号(1958)。

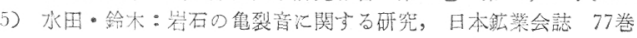
882 号 (昭和36年12月)

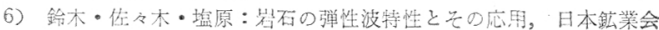
誌 74 管 837 号 (昭和 33 年 3 月)

7) 出村 収: 苩波に上る崩落予知対策, 九州釷山学会誌 30 卷 1 号 (炤和37年1月)

\section{“選鉱成績の表示法”に対するニつの寄書}

日本鉱業会誌 78 巻 890 号32ページ 汇紹介した K. K. MAJUMDAR 氏の “選鍍成績の表示法”之題子る提案 飞対して，二つの意見が The Mining Magazine 誌（1962 年 2 月号 および 5 月号）に寄如ているの でここに要約して見たい。

(1) H. N. Hepker (Assistant Consulting Metallurgist, Anglo American Corporation of South Africa, Ltd.) : 我及注（実収率\% ×選鉱比）という指数を長年使用し ている。その経験から兒て, 結論的 そは，この效率指数だけで成繢の比
較を行ならことは危険である。相詨 的比見た精鉱品位と実收率の経済的

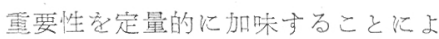
つて得られる修正效率指数老用い万 なら滍，特定の場合に対してのみで はあるが，正しい垀洒が可能である 万。

(2) J. S. JACOBI (Director of Research, Cerro de Pasco Corp., Peru): Majumdra 氏の效率式に対 して HEPKER 氏が指摘した欠点をな くすために，私は修正 Diamond 指 数

$\eta \%=R_{A}+R_{B}-100$ なは

$$
\eta=\left(\frac{f-t}{c-t}\right)\left(\frac{c}{f}-\frac{100-c}{100-f}\right)
$$

$R_{A}$ : 有洒值成分の精鍴実収率 $\%$,

$R_{B}$ : 脈石の除去率 $\%, f:$ フ ード 品位, $c$ : 精鉱品位, $t$ ：尾鉱品位 を用いること老提案したい。

い杀れにせ上，こ机らの物理的效 率式炕よて選鉱成績老完全に評価 することは根本的に望子得ないが， 日常の成績の比較は可能であう5。 一方，経済的次元に就いて総合的に

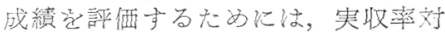
品位の座標系に等価值線老画いた蜗 作図表を用いるとよい。

(并上外志雄) 